\title{
Political Banality in Indonesia Post-New Order
}

\author{
Mukhtar Sarman ${ }^{1}$ \\ ${ }^{1}$ Faculty of Social and Political Sciences, Lambung Mangkurat University, Banjarmasin, Indonesia \\ Correspondence: Mukhtar Sarman, Faculty of Social and Political Sciences, Lambung Mangkurat University, Jl. \\ Brigjen Hasan Basri, Kayu Tangi, Banjarmasin 70123, Indonesia. Tel: 62-812-5444-5400. E-mail: \\ Mochtar_SAR@yahoo.co.id
}

Received: December 9, 2018

Accepted: December 30, $2018 \quad$ Online Published: February 28, 2019

doi:10.5539/jpl.v12n1p64

URL: https://doi.org/10.5539/jpl.v12n1p64

\begin{abstract}
Democratization not only needs to be based on changes in a more democratic political structure, but it is also important to be supported by changes in the behavior of elites involved in political contestation. This article discusses the process of political democratization in Indonesia after the authoritarian New Order regime. The democratization process begins with changes in political structure, which are manifested in the form of various pro-democratic laws and regulations. This includes the implementation of direct regional head election, which are political contestations at the local level. The result was a significant change in political dynamics in the form of involving voters in the process of regional head election. At first everyone tends to recognize the success of political reforms that have changed the face of local democracy in Indonesia. However, after one election period took place, the ideals of democratization in Indonesia seemed to be ignored by political actors. Even politicians tend to display banal political behavior, and do not care about political decay traps, solely in order to win a political contestation. Elite, as the main stakeholder actor, has failed to show that they are able to practice democratic principles that uphold moral integrity.
\end{abstract}

Keywords: banality, democratization, elites, Indonesia, political contestation, political decay

\section{Introduction}

In 1998, there was the beginning of the spring of democracy in Indonesia, known as "political reform". The New Order regime fall down, marked by the resignation of President Soeharto on May 20, 1998. President Habibie, as successor to President Soeharto, agreed with the elites to reconstruct Indonesia's democracy, starting with the publication of a number of Political Laws in 1999, that underlies the accelerated legislative elections in 1999. The implementation of accelerated elections involved 48 political parties, an extraordinary number of election participants because when the New Order era participated it was limited to only two political parties (PPP/The United Development Party, an Islam-based political party, and PDI/Indonesian Democratic Party, as nasionalis-based political party) plus Golkar (Golkar Party), as a political vehicle of the ruling regime. The implementation of accelerated elections was assessed by many foreign observers and international observers as elections who were truly able to display an honest and fair side of political democracy (see for example Antlov and Cederoth, 2004).

The democratization scenario in Indonesia continued with the direct presidential election in 2004. The policy was made after the Third Amendment of the Constitution of the Republic of Indonesia (1945 Constitution) was carried out on November 9, 2001. The presidential election was an unimaginable thing that could happen during the regime Order Baru (1966-1998) in power. Epidently, the presidential election can be implemented well, and looks very democratic, because the contestants who fight can accept the election results without significant objections (see for example Schwarz, 2004; Ananta et.al, 2005).

Based on Law Number 32 of 2004 concerning Regional Government, the process of Direct Elections for Local Leadersalso experienced dramatic structural changes. The Central Government interpreted the Law as a legal umbrella for holding Direct Elections for Local Leadersdirectly by the people (referred to as "Pilkada Langsung" or regional head election), no longer like the previous times, namely when mechanism of choose of regional head were be the authority of the Regional People's Representative Council (Dewan Perwakilan Rakyat Daerah / DPRD).

Since the enactment of the direct regional head election scheme in 2005 , many studies have been conducted on 
its implementation, such as those presented by Erb and Sulistiyanto (2009). There are optimistic stronghold, which insist that the regional head election is a democratic political solution. Moreover, this stronghold is also very confident that the implementation of regional head election has been considered a success story (see for example Liddle, 2012). But there is also a pessimistic stronghold, which considers that the regional head election held so far have marked the low quality of democracy in this country. Pessimistic stronghold see latent symptoms in the form of political overlapping, among others in the form of fraud from the organizers and the existence of a game of money politics from contestants who accompany the implementation of regional head election. This is evidence that as if he negated the intention to actualize the teachings of democracy in political contestation in the local sphere. For those who are skeptical, the existence of political practices that ostensibly deny the idea of democracy and the democratization process are signs that regional head election is not the right model to embody the idea of democracy for Indonesia. For this stronghold, the main issue is actually not the basic character of the Indonesian people, but rather the compatibility of the democratic model that is to be realized (see for example Hadiz, 2010). The argument of the pessimistic stronghold seems to be widely accepted.

The following article may be included in the pessimistic stronghold, but the analysis focuses on one main issue, namely whether the substance of structural changes in the form of legislation that underlies political democratization in Indonesia can be understood by the parties, and triggers the integrity of local elites to practice the rules the nature of democracy in the contestation that involved them.

\section{Materials and Methods}

This study is descriptive and interpretative and mainly relies on secondary data collected from sources such as newspapers, reports from official agencies, and news presented by national television. These sources have recorded events that are relevant to the purpose of this study, namely to reveal the extent to which political praxis in the framework of democratization referring to the scenario of the involvement of the voters in elections, with the main players are contending elites. In addition, secondary data sources also adequately present data relating to the behavior of politicians, since their involvement in the election, until they have gained power as regional heads. Based on the analysis of secondary data, the authors made interpretations, in order to support the arguments developed in this study.

\section{Conceptual Framework}

In generic terms, democracy is a form of government based on people's sovereignty. The people are holders of sovereignty over the state, and to actualize it as a political culture a democratization process is needed - among other things, it can refer to certain models of political democracy that are best suited to available social conditions and conducive to that purpose (see and compare Sorensen , 2008, Held, 2006, Dahl, 1989). Even so, how the real construction of the role of the people in demonstrating their sovereignty actually depends on the adjectives that are attached to the term democracy itself, so the model of democratic praxis is of course various. Even Dryzek, for example, noted that there were 54 adjectives that could be attached to the term "democracy" and made the category of democracy so broad and varied in number (Dryzek, 2004). In other words, the discourse of democracy is actually only a metaphor of the importance of the role of the people in the state order (Axtmann, 2007), while how democratic praxis with all its implications needs to be seen on a case by case basis and depends on objective conditions that support it (Cunnigham, 2002).

The drafting elite of political change in Indonesia Post-New Order saw the urgency of the availability of legislation needed to reform politics in this republic. There are assumptions, in conditions of transition to democracy, the legal umbrella is the main requirement for the establishment of rules of the game and the creation of a good democratization process. With the existence of the rule of law, it is possible for people to be actively involved in the process of influencing public decisions - as happened in Western countries which have matured democratic politics. To achieve the intended condition, then structurally it starts from political participation in general elections, because the order of democracy requires people's sovereignty rights to be formulated as such (Gaffar, 1999).

In the scenario, it is envisaged that citizens need regional head election. Through a democratic mechanism, the population in an area can freely support someone to become the Regional Head, in accordance with their diverse aspirations, and should be with their respective rationalities. In this regard, every actor who becomes a candidate who fights in political contestation is then required to make political commitments, as another interpretation of the importance of "social contracts". The main issues of the social contract offered by candidates are usually not far from the problems of people's welfare and a sense of social justice. The political commitment was made and delivered during the campaign period by the candidates in the form of a vision and mission of the policy program, which is usually oriented to the promises of improving people's welfare. That political commitment is assumed 
could be billed later, when the candidate has been elected as the ruler.

The decision of the Central Government to hold a regional head election such as the like of a Presidential election is a commitment to the spirit of democratization. The Central Government seems to not at all want to do intervention to show an his attitude neutrality. As an organizer for election, done by an independent institution, namely the KPUD (Regional Elections Commission). Whereas as a supervisor of $r$ is an independent institution as well, namely the regional Bawaslu (Election Supervisory Agency). However, with the provision of all the instruments of democratization it seems that it does not guarantee that political democracy can be done as expected. This can be seen from the emergence of various conflicts, which are directly related to the implementation of regional head election.

As an illustration, in 2010, out of 244 regional head election held in 33 Provinces in Indonesia, 230 of them (94.26\%) were known to have led to disputes. A total of 244 regions that held regional head election in 2010 were the same as $38 \%$ of the total regencies/cities/provinces throughout Indonesia. The trend in the percentage of regional head election disputes that entered the Constitutional Court, as an adjudication institution for election disputes, was still high in 2011, 2012 and 2013. Even when the implementation of the elections has changed to be carried out simultaneously since 2015 , because the election disputes on average are still above $40 \%$, although much lower than in 2010 (Table 1). The regional head election dispute was mainly motivated by dissatisfaction with the losing candidates, and they accused the winning party of committing fraud, whether carried out by the success team or assisted by organizers election person in the form of manipulating voter voting data. Even when it comes to contestations involving the incumbent, accusations of fraud can be in the form of corruption by the those in power (Source: Constitutional Court of the Republic of Indonesia).

Table 1. Number of 2010 - 2018 regional election disputes

\begin{tabular}{ccc}
\hline Year & Election implementation & Election in dispute \\
\hline 2010 & 244 regions & $230(94,26 \%)$ \\
2011 & 67 regions & $54(80,59 \%)$ \\
2012 & 77 regions & $59(76,62 \%)$ \\
2013 & 152 regions & $113(74,34 \%)$ \\
$2015\left(^{\text {(a) }}\right.$ & 264 regions & $152(57,58 \%)$ \\
$2017\left(^{\text {() }}\right.$ & 101 regions & $60(59,41 \%)$ \\
$2018^{(c)}$ & 171 regions & $70(41,94 \%)$ \\
\hline
\end{tabular}

Note: since 2015, simultaneous regional elections have been carried out in Indonesia, based on Government Regulations in Lieu of law Number 1 of 2014.

(a) Some of them include the term of office of the regional head which should have expired in 2014.

(b) Some of them include the term of office of the regional head which should have expired in 2016.

(c) Some of them include the term of office of the regional head which should have expired in 2014.

Source: General Election Commission of the Republic of Indonesia.

The data compilation that illustrates the amount cases of regional head election conflict as if justifies Huntington's point of view about the symptoms of political decay. Huntington (1965) states that the political phenomenon of hitching is characterized by a weakening of the ability of political institutions to manage the actions of the factions fighting for power. Political development has its own logic, which is related to the socio-economic dimension, but differs from economic and social logic. Political decay occurs when the socio-economic dimension is mixed into the political realm, and the mobilization of new social groups mendapatkan who gain power bisa cannot be accommodated in the existing political system. Political order emerges as a result of achieving some balance between the forces competing in a society. But over time, changes occur internally and externally where the actors who form the original balance develop or disappear, and then new actors emerge with their own roles. As a result, the previous balance did not play a role, and the results of political decay invited new actors who came up with a new set of rules and institutions to restore order. This is evidenced by the fact that there were instabilities of newly independent countries in developing countries during the 1950s and 1960s (Huntington, 1968). One of the things Huntington suspected as a factor because of the 
emergence of symptoms of political decay was corruption in political institutions, and this was also indicated in Indonesia (Aspinall and Fealy, 2010). Corruption does indeed cause insufficient functioning of political institutions to regulate social order in power relations, but corruption is not isolated from institutional dysfunction (Gingerich, 2007).

However, it should be noted that the conflict of Direct Local Election brought to the realm of law is generally only reported or opened to the public space after the vote count is done by the Regional Election Commission, and it is known who the winner of the contest. Usually the losing party feels that they have been cheated because their political opponents vote buying, or use money politics to give persuasions to voters, or doing intimidate, and so on, which constitute offenses of election violations during the campaign and voting period. Even though it does not mean the reporting party does not commit the same fraud (Sarman, 2014). It is evident that the court cases of fraud in the regional head election have never succeeded in changing the final results of the election, for various reasons which are sometimes very summons (Sarman, 2015). Therefore, it is questionable why the contestants actually indulged in fraud cases of political opponents precisely after the vote count was finished. As if they were not sincere with their defeat. It was as if they did not know that the dispute in political contestation had very little chance of winning, other than spending money. The explanation is impossible to obtain by only relying on the political logic of decay. There needs to be an introduction to other, more sophisticated concepts, and the concept to be offered in this study is political banality.

Banality in the context of the election dispute case is "misguided" done by the subject in understanding the meaning of power, both in terms of how to obtain it and in terms of how to use it (Sarman, 2016). Misguided is a term commonly used to indicate a judgment that is considered true, but is actually wrong; and the actions taken based on the assessment by the perpetrators are believed to be actions that do not violate the norm. Behind the use of this term there is an awareness of the ambiguity about how that power is obtained or used. The symptoms appear may also be due to forced rationalization, or simply because of mere carelessness.

Banality is actually a neutral concept as the interpretation of a person as an independent subject about the truth of an entity based on its rationality. This concept becomes biased when it is associated with political reality. This happens because in the political sphere that has the authority to interpret something political reality is the elites. While elites usually have an interest in interpreting political reality. They are able to impose on society as a whole an explanation and justification for their power over a system of political and economic domination (Marger, 1987). In Scott's (2007) study, elites were described as being able to develop it through the structuring of power to ensure the continuity of their relationship of dominance. They usually coalesce into small units that dominate through the mediation of power, and make all important decisions in allocating values about politics in the sense of power.

\section{Discussion}

Regional head election displays unhealthy political contestation, if viewed from the standpoint of the standards of liberal democracy. The adoption of this standard makes the political praxis that takes place can be categorized as "low quality". The rise of cases of the practice of money politics is indicative of a systemic overlap, and results in skepticism. In the coverage of this skepticism there is an assessment that democracy in Indonesia has been hit by a deficit or a "legitimacy crisis" (Luckman, et. al., 2000). From this expression it is also revealed that the values contained in the idea of democracy are not only imperfectly actualized, but tend to be abandoned by those who should practice the teachings of democratic politics. In other words, the implementation of regional head election is burdened with integrity issues. Integrity, especially in the case of regional head election disputes, in addition to personal morals, is also related to the ability to apply democratic principles. This shows the symptoms of a democratic deficit, which in certain perspectives can be categorized as the existence of symptoms of "banality of power", namely the superficial understanding from actors about the nature of power, for what must be owned, and how to obtain it.

Banality in the political context is believed to be systemic in character, characterized by the working of a monopolistic power structure, and corrupt behavior, and the relationship between the two is ignored. This is discussed in depth by Scott (1989). He explicitly stated that corruption is often an integral part of the political system, but we tend to ignore it. Its presence is not understood as a major danger to the management of public destiny. Indeed, the corruption that occurred in the political institutions became the trigger that triggered public distrust over the performance of the institution. Corruption is then seen as a disease of the political body, which in the expression Friedrich is regarded as "the disintegration of the belief system upon which a particular political system rests" (Friedrich, 1989). This view is far broader than just seeing corruption as an economic issue involving individual impropriety. Friedrich notes that this idea is broader than the history of corruption that 
has developed into the notion of "modern corruption", which means the abuse of public power for personal gain.

The banality of power takes place when political elites and contestants respond to political contestations according to their own version and interests. They may feel that they are not burdened to maintain standards of behavior and actions to be in accordance with the norms that support the mechanism of direct and healthy elections with integrity, as described by Annan (2012). That happened until, perhaps, because they considered this politics of integrity not realistic to be realized. In this context fraud and money politics is a necessity.

The symptoms of money politics are recognized to have been a decisive element in political practice in Indonesia during the era of democratic transition (Aspinall, 2005). This symptom, as delivered by Aspinall, is commonly used in several Southeast Asian countries (especially Indonesia, Malaysia and the Philippines). But according to Aspinall the term "money politics" is not appropriate, except when it is associated with two important terms of political science, namely patronage and clientelism (Aspinall, 2013). Apart from the issue of accuracy of terminology, the opinion of the Aspinall seems to be equivalent to the symptoms in this study called political banality which is assumed to trigger anomalies in the practice of democracy.

The important issue to be highlighted here is that political banality concerns the interrelationship between various things. In the study of Kitschelt and Wilkinson (2007), patronage and clientelism are used in the context of the provision of goods or other assistance exchanged in political relations. Referring to studies in Africa, India, Latin America and Japan, Kitschelt and Wilkinson further illustrated the character of patronage in party and voter relations. In many political systems constituent relations and many politicians are based on material persuasions that are directly targeted at small groups of citizens who know politicians are very responsive to the payment side and are willing to submit their votes for the right price. Reality in the field shows clientelistic accountability is a direct transaction or exchange of votes of citizens in exchange for cash payments, or promises of access to jobs, goods and services.

Kitschelt and Wilkinson point out the main problem that tends to be dilemma from clientelism and patronage in the form of compensation that can be enjoyed by both parties - politicians may not want to follow up on their promises to provide public services after they are elected, and voters may not want to vote for politicians because they have receive the service. Allegedly because of such political dialectics, clientelism usually tends to decline in accordance with various reasons for the reduction in poverty which makes people more expensive to buy support. Indeed clientelistic politics in many places can increase voter support. It was also proven by Wantchekon in his study in Benin, West Africa, and significantly negatively correlated with income, education and housing quality and the size of the population (Wantchekon, 2003). In other words, clientelism theory is nothing but "protective politics" which are formulated in the form of income transfers or public goods channeled by politicians to bind the continuation of voter support; and this is interpreted in Indonesia as "money politics". Though formally ordinary money politics is defined as "vote buying" (Girling, 1997).

Banality is closely related to the political context to get political support. The contestants respond to certain contexts, and the response is not necessarily understood by people who are not involved in the transaction. Due to the widespread practice of money politics, things that are more essential are actually not money, but transactional bonds that are interwoven. Therefore, Aspinall and Mietzner (2010) explain that the term money politics in Indonesia is actually not always relevant to the existing formal definition. Transactions that take place can be disclosed in the form of donations [money] and assistance [goods] to constituent groups in poor areas. For voters, it is considered evidence that political parties or candidates who do so are concerned about them and [may be] because it is a reason to be eligible for election. Because of this pattern, in Palmer's (2010) view, money politics in Indonesia is a legitimate part of political campaigns; and such money politics have never been the cause of the failure of the victory of political parties or candidates in elections [or regional head election].

The close practice of money politics is related to the cultural preferences of the community about "reciprocate good politics". This was demonstrated in Braithwaite and Dunn's study when observing the Maluku gubernatorial and North Maluku election conflicts (2010). Previously the same thing was reported in a study conducted by Hadiz, taking the case of the selection of 22 regents and mayors in North Sumatra (Hadiz, 2005).

Banality of power involves the division of roles from various parties involved in the transaction. For the continuity of money politics, donors role specialization has developed. By focusing on the importance of the role of donors in gathering the "political funds" needed to win the regional head election contestation, Mietzner pointed out that in the case of Governor elections in South Sulawesi (2007) and West Java (2008) involving a number of donors. Efforts to raise political funds cannot be avoided because the facts on the ground show how much the costs incurred by candidates for public vote support (Mietner, 2011). Such research can show the reason why money politics, with its various types and modes, can occur and be present in political dynamics in 
Indonesia. However, such an analysis does not explain the hidden structure behind the practice of money politics, and how the trajectory is related to local political traditions. For example, money politics can be related to a patronage pattern that specifically applies to a particular community and value system - because not everyone can make maximum use of the positive value of money politics to win political contestation. Or, it could be that the practice of money politics does not apply to certain communities, because for example it relates to the existence of local customs.

The practice of money politics is considered as a form of deviation from democratic political norms, and it may be carried out by elite and candidate actors to win political contestations involving themselves. The problem is that any deviation from political norms when they do it consciously as an unavoidable thing actually reflects that they are trapped in the banality of power. The articulation of democratic political meaning seems to be lost amidst the complexity of the democratization process. Of course, there is a rationalization and justification that justifies this action. In this context, the problem is not any form of norm deviation that occurs and is considered inappropriate to do, but why it is inevitable. In its praxis, banality seems to be an inseparable part of the political contestation required in the design of liberal democracy.

Based on these assumptions, actually the practice of money politics is a rational choice if you want to win a political contestation based on the principle of gathering as many votes as possible. The problem is, to implement such a winning strategy requires very expensive political costs. The Ministry of Home Affairs research institutions data said that the cost of becoming regents / mayors reached IDR 20 billion to IDR 30 billion, while for the governor it needed a fee of up to IDR 100 billion (The Indonesian Ministry of Home Affairs, 2015). Whereas, from year to year the amount of funds needed is increasing. From where did the candidates who fought in the regional election contest get such large political funds?

The Indonesia's Corruption Eradication Comission (Indonesia: Komisi Pemberantasan Korupsi [KPK]) on its study in 2017 justified the political costs of participating in the regional election contestation, the higher the year. For the gubernatorial election, it even requires political costs of IDR 100 billion to IDR 300 billion, depending on the area and the number of voters targeted. These costs do not include 'political dowry', namely the price of support that candidates must pay to be carried by a political party or a combination of political parties - whose value can reach IDR 100 billion rupiah (Sarman, 2015). Because not all candidates are rich people, there is a transaction between candidates who fight in regional election contestation with strongmen local or capital broker, who act as sponsors. The candidates promise with the sponsors, and will pay for their good services if they have served as Regional Head.

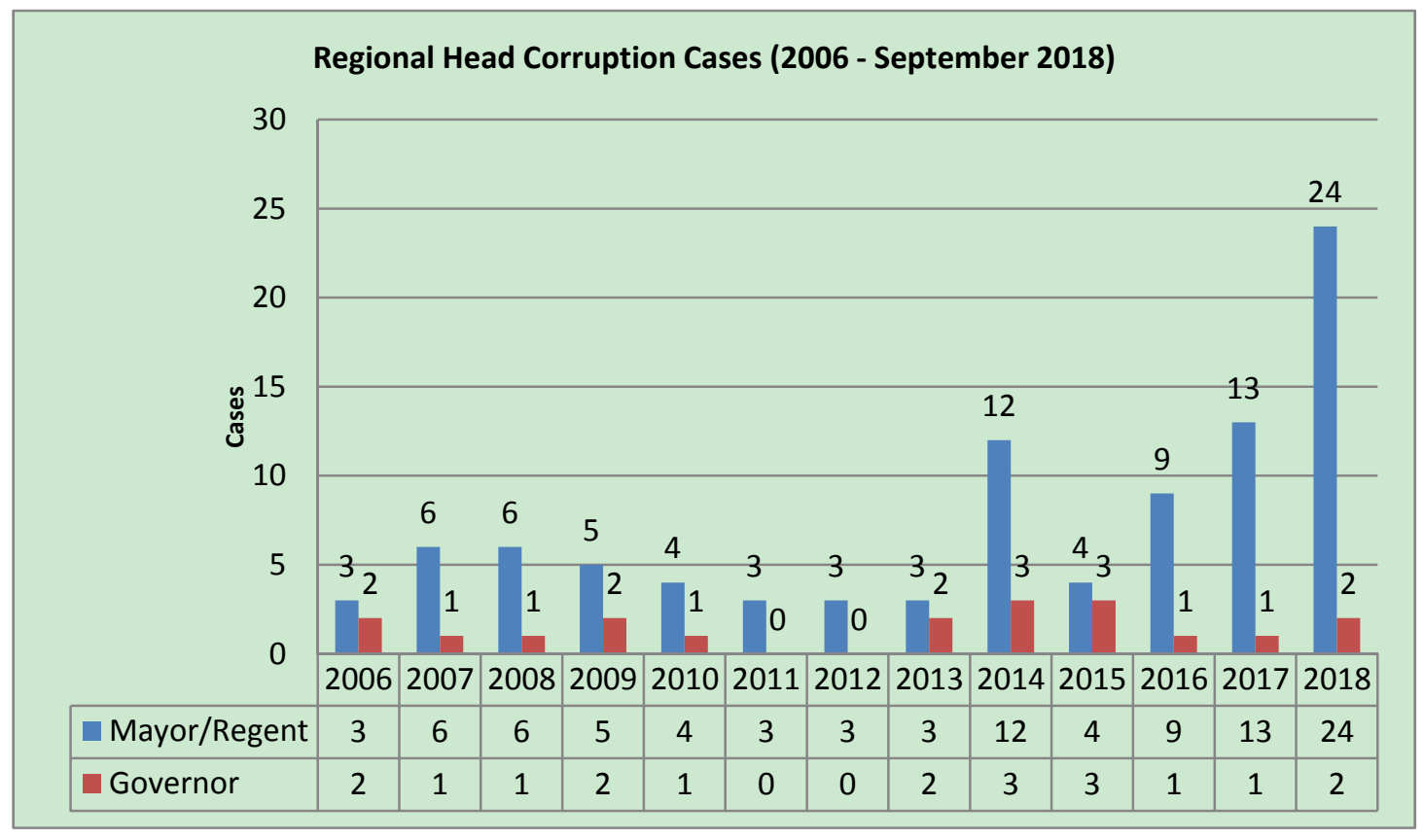

Figure 1. Regional head corruption in Indonesia

It may be because it is bound by a promise with the sponsor that many Regional Head officials are entangled in 
rents, and try to maximize the opportunity to manipulate APBD (Regional Goverment Budget) funds. A number of Regional Heads, both Regents / Mayors or Governors, were later caught up in the Regional Budget corruption. They carry out acts of corruption with various modes that concern their authority as authorities in the regions. Figure 1 visualizes the regional heads of "perpetrators of corruption" who were arrested by the KPK during 2006-2018. It was recorded, from 2006 to September 2018, no less than 114 Regional Heads were arrested by the KPK (Kompas Daily, 26 October 2018). They consist of Mayor / Deputy Mayor and Regent / Deputy Regent, as well as 20 Governors. This mode of corruption often occurs jointly with DPRD (Dewan Perwakilan Rakyat Daerah [Regional House of Representatives]) members; even with DPR (Dewan Perwakilan Rakyat [House of Representatives]) members, when they agreed to manipulate regional development funds originating from the state budget source. Data released by the KPK showed that 205 DPR/DPRD members had been arrested and underwent legal proceedings with corruption crimes within the period 2007 to May 2018 (source: Indonesia's Corruption Eradication Commision, 2018). Figure 2 visualizes the DPRD/DPR members of "perpetrators of corruption" who were arrested by the KPK during 2007 - May 2018.

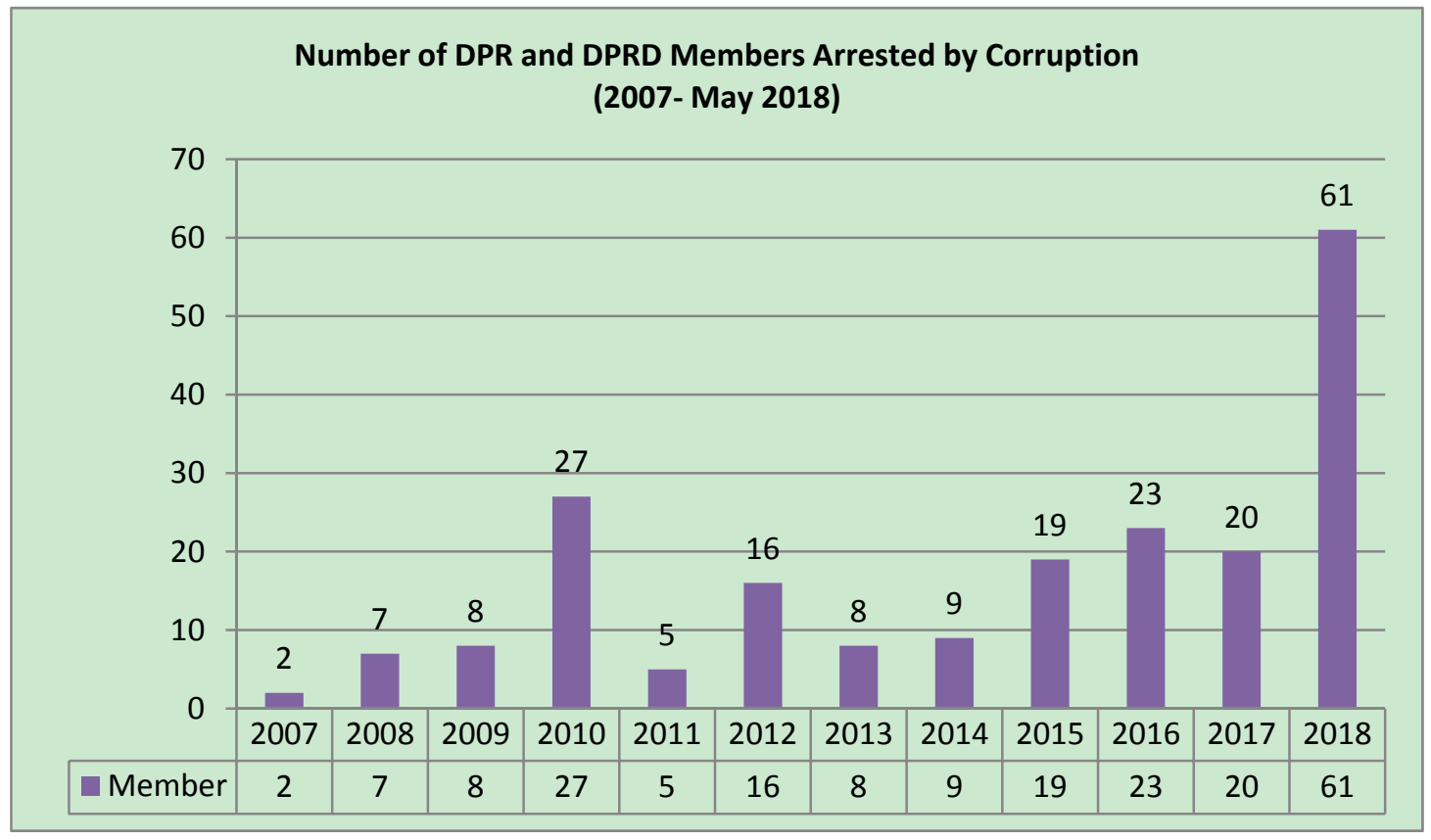

Figure 2. Number of DPR and DPRD Members Arrested by Corruption

Then what is the connection between the regional head who is caught in corruption and arrested by the KPK with a political banality concept? Banality is the inability to understand the substance of the truth when someone is faced with the accusation that he is actually guilty. Someone trapped in banality does not feel guilty for his reckless actions and morally has a negative impact on the people. Although "paying off debt" during the campaign period is not the only reason for corruption, of course, it cannot be denied when a Regional Head steals state money through his authority as a regional ruler. As the Regional Head, he can use all expenditure funds originating from the APBD, for the benefit of his supporters when the campaign for regional head election, or may be for his own benefit. As Regional Head, he can give concessions, etc., which are related to his authority to give permission to work on natural resources in his area. Whereas, as the Regional Head, at the time of the campaign he promised to prosper the people in his area. It may be because he believes in the political promise, the people agree to support him, and win him in the contestation of the elections.

Unfortunately, when the Regional Head was arrested by the KPK on charges of corruption, generally there was no feeling of unease on their faces. From observations of a number of Regional Heads who were arrested by the KPK so far, only one person appeared to imply a face of remorse when arrested, namely Zumi Zola, governor of Jambi for the period 2016-2021. Before being arrested by the Corruption Eradication Commission, Zumi Zola, known as the governor which performed well, and became the governor and continued his parents' career, which had also been Jambi's previous governor. In the trial of his case, Zumi Zola immediately acknowledged openly his mistakes, and apologized to all the people of Jambi, and crying when reading his defense note (Kompas Daily, November 22, 2018). Whereas the other suspects were corruptors who in front of the television cameras showed 
a cheerful face, as if they were not guilty at all. The cheerfulness shown, even though it does not describe the true contents of their hearts, is a form of theatrical depiction of banality.

More or less what was demonstrated by the corruption suspects arrested by the KPK was probably similar to what Arendt had imagined about Adolf Eichmann's behavior, a war criminal who would be punished by the Jerusalem court for his involvement in the Jewish genocide. In Arendt's report, Eichmann appeared to show no remorse on his face. He does not seem to feel guilty for his actions which are considered by people as extraordinary crimes of humanity. He seemed to go to the gallows with pride and pride. Even silly refused the black hood to cover his head. And that is an indication of the existence of banality, namely the shallowness of the subject in interpreting a substance - which in Eichmann's case is the substance of the crime he committed (see Arendt, 1963: 118-9 and 134-5).

Corruption in the rule of law in Indonesia has included extra-ordinary crime. However, the perpetrators of corruption, in this case the Regional Heads, as if they do not want to know the rules. For a variety of rational reasons, although sometimes forced, making the perpetrators forget aspects of morality in the crime. Perhaps that is what lies behind their appearance as if they were not burdened with the title of corruption suspect. They can display a big smile in front of a television camera, like a celebrity being consulted by the television crew covering it. Although finally the smile will disappear without a trace when the sentence has been dropped by the court judge.

\section{Conclusion}

The prominent of political banality phenomenon in the process of institutionalizing political contestation was a sign that the parties involved in the contestation were as if they were unable or unprepared for democracy, as demanded by advocates of the liberal democratic system. Elite, as the main stakeholder actor, has failed to show that they are able to practice democratic principles that uphold moral integrity. For anyone who views democratic principles as important in the process of democratization, the negative effects of elite behavior trapped in political banality clearly have bad implications on how ordinary people perceive elections as instruments of political democracy.

The conceptualization of democracy inevitably eventually drags on the problem of win-lose, because the key idea behind the implementation of regional head election is about who the winner is. From the candidate's point of view, the basic idea of contestation is "I have to be the winner". In this context, there has been a discourse dislocation where the process of change is not on improving the quality of democracy, but on the idea of determining which contestation winner. The idea of "equal rights of citizens" implied behind the holding of elections has shifted into an idea of contestants and contestation. The political contestation that was quietly formatted was all out, so that in that case it would not be logical if the moral commitment of the contestants involved should be prioritized. The contestants may be a person who privately split. Contestants may realize that they have committed a moral offense, but he is also aware that he must avoid the risk of losing in the political fight he follows.

Acknowledgments: This essay is self-funded by the author.

Conflicts of Interest: The author declares no conflict of interest

\section{References}

Ananta, A., Arifin, E. N., \& Suryadinata, L. (2005). Emerging Democracy in Indonesia. Singapore: ISEAS. https://doi.org/10.1355/9789812305527

Annan, K. (2012). Deepening Democracy: A Strategy for Improving the Integrity of Elections Worldwide. Geneva: International Institute for Democracy and Electoral Assistance.

Antlöv, H., \& Cederroth, S. (2004). Elections in Indonesia: The New Order and Beyond. London: RoutledgeCurzon.

Arendt, H. (1963). Eichmann in Jerussalem: a Report on the Banality of Evil. New York: Penguin Group, Inc.

Aspinall, E. (2005). Opposing Suharto: Compromise, Resistance, and Regime Change in Indonesia. California: Stanford University Press.

Aspinall, E., \& Mietzner, M. (Eds.). (2010). Problem of Democratisation in Indonesia. Singapore: ISEAS Publishing. https://doi.org/10.1355/9789814279918

Aspinall, E., \& Fealy, G. (Eds.). (2010). Soeharto's new order and its legacy: essays in honour of Harold Crouch. Australia: ANU E Press, Canberra. 
Aspinall, E. (2013). Money Politics: Patronase and Clientelisme in Southeast Asia. In W. Case (Ed.), Handbook of Democracy in Southeast Asia. London and New York: Routledge.

Aspinall, E., Jeffrey, R., \& Regan, A. J. (Eds.). (2013). Diminishing Conflicts in Asia dan the Pasific. London and New York: Routlegde.

Axtmann, R. (2007). Democracy: Problem and Perspectives. Edinburgh: Edinburgh University Press.

Braithwaite, J., \& Dunn, L. (2010). Maluku and North Maluku. In J. Braithwaite et al. (Eds.), Anomie and Violence: Non-truth and Reconciliation in Indonesia Peacebuilding. Canberra, Australia: ANU E Press. https://doi.org/10.22459/AV.03.2010

Cunningham, F. (2002). Theory of Democracy: A Critical Introduction. London: Routledge. https://doi.org/10.4324/9780203466247

Dahl, R. A. (1989). Democracy and Its Critics. Connecticut: Yale University Press.

Derber, C. (2004). Regime Change Begins at Home. San Fransisco, California: Berrett-Koehler Publishers, Inc.

Dryzek, J. S. (2004). Democratic Political Theory. In G. F. Gaus, \& C. Kukathas (Eds.), Handbook of Political Theory. London: SAGE Publications. https://doi.org/10.4135/9781848608139.n11

Erb, M., \& Sulistiyanto, P. (Eds.). (2009). Deepening Democracy in Indonesia?: Direct Elections for Local Leaders (Pilkada). Singapore: ISEAS Publishing. https://doi.org/10.1355/9789812308429

Friedrich. (1989). Corruption concepts in historical perspective. In A. Heidenheimer, M. Johnston, \& V. T. LeVine (Eds.), Political Corruption: A Handbook. New Brunswick: Transaction Publishers.

Gaffar, A. (1999). Politik Indonesia: Transisi Menuju Demokrasi [Indonesian Politics: Transition Towards Democracy]. Yogyakarta: Pustaka Pelajar.

Gingerich, D. W. (2007). Corruption and Political Decay: A Causal Analysis based on the Bolivian Case. (Post-doctoral Research Associate Center for the Study of Democratic Politics. Princeton University, April $30,2007)$.

Girling, J. (1997). Corruption, Capitalism and Democracy. London: Routledge.

Hadiz, V. R. (2005). Reorganizing Political Power in Indonesia: A reconsideration of so-called democratic transitions. In M. Erb et al. (Eds.), Regionalism in Post-Suharto Indonesia. London and New York: RoutledgeCurzon.

Hadiz, V. R. (2010). Localising Power in Post-Authoritarian Indonesia. California: Standford University Press.

Held, D. (2006). Models of Democracy. Cambridge: Polity Press Ltd.

Huntington, S. (1965). Political Development and Political Decay. World Politics, 17, 386-430. https://doi.org/10.2307/2009286

Huntington, S. (1968). Political Order in Changing Societies. Connecticut: Yale University Press.

International Crisis Group. (2010). Indonesia: Mencegah Kekerasan dalam Pemilu Kepala Daerah [Indonesia: Preventing Violence in Regional Head Elections]. Asia Report no.197. 8 Desember 2010.

Kitschelt, H., \& Wilkinson, S. (2007). Citizen-politician Lingkages: An Introduction. In H. Kitschelt, \& S. Wilkinson (Eds.), Patron, Client and Policies: Pattern of Democratic Accountability and Political Competition. Cambridge: Cambridge University Press. https://doi.org/10.1017/CBO9780511585869.001

Liddle, W. (2012). Memperbaiki Mutu Demokrasi di Indonesia: Sebuah Perdebatan [Improving the Quality of Democracy in Indonesia: A Debate]. Jakarta: Yayasan Paramadina.

Luckman, R. et al. (2000). Democratic Institutions and Politics in Contexts of Inequality, Poverty, and Conflict: A Conceptual Framework. IDS Working Paper 104. Brighton: Institute of Development Studies.

Marger, M. (1987). Elites and Masses: An Introduction to Political Sociology. Belmonf, California: Wadsworth Publishing Company.

Mietzner, M. (2011). Funding pilkada: illegal campaign financing in Indonesia's local elections. In E. Aspinall, \& G. van Klinken (Eds.), The State and Illegality in Indonesia. Leiden, The Netherlands: KITLV Press. https://doi.org/10.1163/9789004253681_008

Palmer, B. (2010). Services Rendered: Peace, Patronage and Post-conflict Elections in Aceh. In Aspinall, \& Mietzner (Eds.), Problem of Democratisation in Indonesia. Singapore: ISEAS Publishing. 
Robison, R., \& Hadiz, V. R. (2004). Reorganizing Power in Indonesia: The Politics of Oligarchy in an Age of Markets. London and New York: RoutledgeCurzon.

Sarman, M. (2014). Banalitas Kontestasi Politik; Refleksi Pemilu Legislatif di Kalimantan Selatan [Banality of Political Contestation; Reflections on the Legislative Election in South Kalimantan].

Sarman, M. (2015). Pilkada Serentak: Quo Vadis Kedaulatan Rakyat [Simultaneous Local Election: Quo Vadis People's Sovereignty].

Sarman, M. (2016). Praksis Demokrasi yang Rumpang: Kasus Pilkada Langsung di Kalimantan Selatan [Praxis of Democracy Decay: The Case of Direct Election in South Kalimantan]. (Unpublished doctoral dissertation). University of Gadjah Mada, Yogyakarta, Indonesia.

Scott, J. (1989). Handling Historical Comparasions Cross Nationality in Comparative Political Corruption. In A. Heidenheimer, M. Johnston, \& V. T. LeVine (Eds.), Political Corruption: A Handbooks. New Brunswick: Transaction Publishers.

Scott, J. (2007). Power, Domination and Stratification: Towards a Conceptual Synthesis. Sociologia, 55, 25-39.

Sorensen, G. (2008). Democracy and Democratization: Processes and Prospects in a Changing World. Colorado: Westview Press.

Schwarz, A. (2004). Indonesia: The 2004 Election and Beyond. Singapore: ISEAS. https://doi.org/10.1355/9789812306180

Wantchekon, L. (2003). Clientelism and Voting Behavior: Evidence from a Field Experiment in Benin. World Politics, 55(3), 399-422. https://doi.org/10.1353/wp.2003.0018

\section{Copyrights}

Copyright for this article is retained by the author(s), with first publication rights granted to the journal.

This is an open-access article distributed under the terms and conditions of the Creative Commons Attribution license (http://creativecommons.org/licenses/by/4.0/). 